\title{
Transport Intermodal Interchanges: Socio-Economic Impacts at Lille European Metropolis
}

\author{
Odile Heddebaut \\ Researcher, UPE-IFSTTAR AME-DEST Paris, France \\ Floridea Di Ciommo \\ Responsible for research area, CENIT-UPC Barcelona-Tech, Spain
}

\section{SUMMARY}

Within the framework of the "City-HUB" FP7 European research project 27 interchanges were studied in nine European countries. It investigated how transport interchanges work from the point of view of governance and the organization of facilities. On this basis a typology of interchanges has been defined for classifying the interchanges and selecting the key elements for improving the interchanges location, construction, and organization of an interchange.

The paper focus on the implementation of the City-HUB interchange typology to the case study of Lille European Metropolis (MEL) where two contingent railways stations Lille Flandres and Lille Europe were analysed as a potential unique interchange. Indeed, the article is related to the creation of a joint interchanges able to attract more public transport users than private users such as it is now the case.

These two main railways interchanges have different territorial and transport functions (i.e. one is oriented to regional traffic and the other one to national and international traffic). Urban planners and transport authorities would like to connect both stations creating a unique interchange.

A key point of the Lille's City-HUB analysis is related to the involvement of the stakeholders. Their involvement is at the origin of the interactions between City-HUB and its socio-economic and urban context. We demonstrate that combining transport and land use planning policies could boost commercial development, new business offices or housing. The urban City-Hub overcomes its role of transport infrastructure for being a "place".

\section{INTERCHANGE GOALS}

Public transport hubs in many European cities are often designed for different scale functions. They can provide new functions and determine new roles for national rail and road network accessibility, creating new hierarchies within cities. They can have a very important function within the regional planning context providing new urban centralities. For instance Lille, that was previously at the end of the French networks, being placed at the crossroad of the Northern high speed train network have changed its role becoming more central within the European transport network, in connection with different sub-regional areas with access to regional trains, intercity buses. Multimodal poles are also integrated into urban and local land planning. They can produce urban regeneration of some areas and be part of a transport oriented development (TOD) policy such as in the urban sustainable 
mobility plan (LMCU, 2010).

The ultimate function of an interchange is to easily transfer from one mode of transport to another. The main idea is to facilitate intermodal transfers, increase the sustainable transport mode use, and reduce the total journey time, improving the quality of service. Interchange nodes are oriented to coordinate modes from private car modes, rail to urban public transport and to non-motorised transport modes such as private bicycles and public bike sharing services or ease walking access or egress.

The co-ordination of modes is related to the involvement of different stakeholders in a common governance framework for planning interchange practices and urban space with an urban sustainable scope.

\section{METHODOLOGY}

\subsection{Literature reviews}

A clear definition of interchange was elaborated by the Madrid Regional Transport Authority in 1985 with a vision of making them accessible, working and convenient i.e.: an "Area whose purpose is to minimize the inevitable sensation of having to change from one mode of transportation to another, and efficiently using the inevitable waiting time" (CRTM, 2010). Di Ciommo et al. (2014) show that users identify the improvement of city-hubs with the quality of time spent inside. The current challenge of interchanges is to facilitate transfer from the use of private motorized vehicles to a shared use of cars (i.e. car sharing or carpooling), to the use of public transport, and non-motorized modes. It is, in a certain way, a planning principle. A comfortable and practicable connection by platforms, information systems, bike and ride options, and pedestrian flows organization around an interchange, will be the pivot for designing, constructing and renewing interchange spaces. Travel intermodality could become a real policy goal for providing passengers with seamless journeys even when they use a combined trip chain.

An inter-modal interchange includes two main categories of aspects: they related to the internal functions (i.e. wayfinding, opportunity space, inter-modes distances, etc.) and the other ones concerning the urban environment related to its impacts on the land use or constraints by the land use around the interchange.

The aim of an interchange will generally be oriented to improve the quality of public transport services and support seamless door-to-door travel. But nowadays an interchange is more than a simple node in a transport network; it includes many elements. Research literature shows that the benefits of urban interchanges relate to time savings, better use of waiting times, urban integration, and improved operational business models (Di Ciommo, 2009). Besides accessibility improvements, management, and innovation, an efficient use of interchanges should also be considered.

On the basis of analysed interchanges in the City-HUB project we have established a typology capturing different interchanges and a scheme for scoring their characteristics in terms of function and logistic dimensions (demand, number of transport modes, services and 
facilities, location in the city) and their local constraints (Di Ciommo et al., 2016). In particular, the first group of aspects (Dimension A) is related to the internal functions and logistics of an interchange, including transport elements of the interchange and the services and facilities necessary to fulfil the transfer functions properly. This dimension determines the size of the terminal building. The second group (Dimension B) includes the external aspects of the city environment that affect how the building could be in reality. This dimension includes the location of the interchange within the city and whether or not the interchange plan is in conflict with the existing land uses in the surrounding area.

Table 1 Interchange Dimensions: Function and Logistics, Local Constraints

\begin{tabular}{|c|c|c|c|}
\hline $\begin{array}{l}\text { Dimension } A \\
\text { Function and Logistics }\end{array}$ & Levels & Need for space & Score \\
\hline \multirow{3}{*}{ Demand (users/day) } & $<30,000$ & Low & 1 \\
\hline & $30-120,000$ & Medium & 2 \\
\hline & $>120,000$ & High & 3 \\
\hline \multirow{3}{*}{ Modes of transport } & Dominant - bus & Low & 1 \\
\hline & Dominant - rail & Medium & 2 \\
\hline & Several modes and lines & High & 3 \\
\hline \multirow{3}{*}{ Services and facilities } & Kiosks, vending machines & Low & 1 \\
\hline & Several shops and basic facilities & Medium & 2 \\
\hline & Integrated shopping mall with all facilities & High & 3 \\
\hline $\begin{array}{l}\text { Dimension B } \\
\text { Local constraints }\end{array}$ & Levels & Upgrading level & Value \\
\hline \multirow{3}{*}{ Location in the city } & Suburbs & Less & - \\
\hline & City access & Neutral & o \\
\hline & City centre & More & + \\
\hline \multirow{3}{*}{$\begin{array}{l}\text { Surrounding } \\
\text { features }\end{array}$} & Non-supporting activities & Less & - \\
\hline & Supporting activities & Neutral & o \\
\hline & Strongly supporting activities & More & + \\
\hline \multirow{3}{*}{ Development plan } & None & Less & - \\
\hline & Existing & Neutral & o \\
\hline & Existing and including intermodality in the area & More & + \\
\hline
\end{tabular}

The values given in Dimension A determine the need for space: interchange size. Total score lower than 4 requires a Small interchange. Scores 5-7 indicates the need for a Medium one, while higher than 8 means that the interchange should be rather big, becoming an urban Landmark. Dimension B aspect could be negative, positive or neutral, modifying in this way the previous scores and the type of required interchange.

Based on this typology, the Lille interchange gets a score of 9 because its demand is higher than 120,000 in daily passengers, includes 13 public and private transport modes (several PT, car and bike), and is located in the inner city centre. It is included into a local plan of urban development and TOD definition. The twin Lille interchange has all the characteristics for becoming an urban Landmark for the city of Lille.

\subsection{Managing interchanges}

Once defined the typology of an interchange and urban planning, the second relevant aspect is its managing and the behind governance regulation.

The governance framework was specified through carring out semi-structured interviews with key interchange actors for each City-Hub case study (Popelier et al., 2016).

The template was divided into four parts to address the different aspects that are relevant for validating the City-HUB model. In the first part, the responsible case study partner needed 
to provide a description of the interchange, which included a description of the background, history, location and mode of transport at the interchange. It was also necessary to identify the main stakeholders that are involved at the interchange and explain the main legal requirements that may affect the planning and operation. The second part of the template was to explain how data collection had been conducted (which actors have been interviewed) and the process for reaching conclusions. The third and fourth part were oriented to use the City-HUB model in order to assess the interchange status and validate the model.

Interviews were conducted with four categories of practitioners: 1) the interchange managers from the body (bodies) in charge of the interchange operations; 2), the public transport operators at the interchange; 3 ) the decision makers and /or public administration in charge of planning transport investments and organisation. This group consists of the relevant transport authorities in the region; 4) Facility/estate owners and/or estate companies because those are often the main actor at interchanges in charge of the construction and maintenance of the interchange. They were also questioned about the role of interchanges in local economies and their potential impact on that.

\section{LILLE FLANDRES AND LILLE EUROPE INTERCHANGES}

\subsection{The place of the interchanges as node}

The main reason for developing a joint interchange as a node is to reduce car dependency and increase public transport use. It also can increase urban density or even create completely new neighbourhoods. The French Lille interchange is composed of two main railways stations in the Lille European Metropolis (MEL). Effectively, they are located near each other at about 500 metres in the "railway stations triangle" and offer possibilities to transfer from urban public transports to rail services at mainly regional level for the Lille Flandres station and mainly at national and international level for the Lille Europe station. These two interchanges are located at a hub on the regional, national and international High speed train rail network linking France to United Kingdom, the Netherlands, Germany, and Belgium (figure 1). 


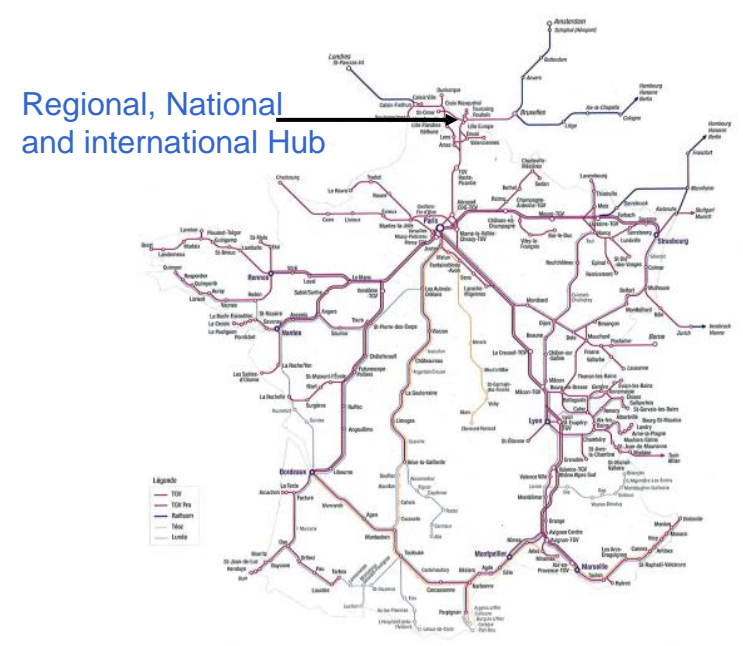

Source: TGV and Railteam network, TGV Magazine, December 2013

\section{Figure 1: The place of the Lille transport interchanges within the French and international railway network.}

A big shopping mall named Euralille is located between the two stations (figure 2).

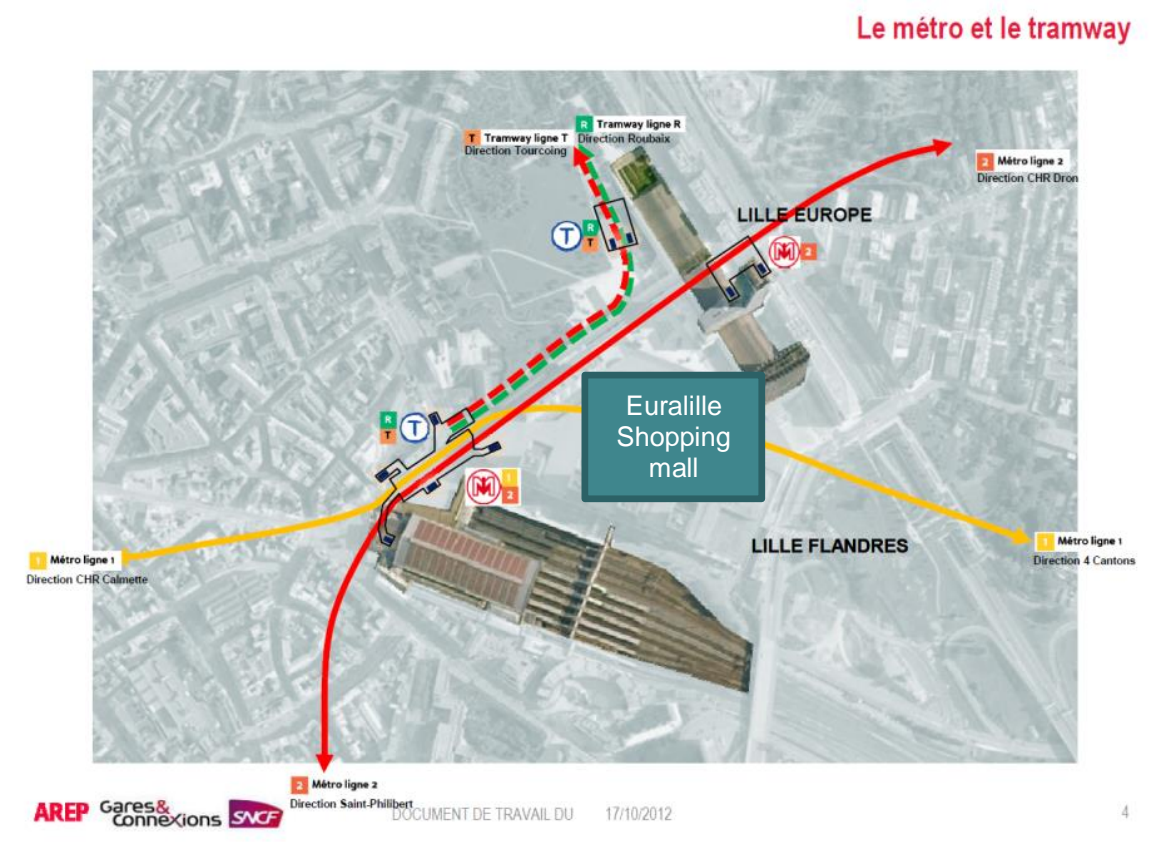

Source: Gares \& connexions SNCF

Figure 2: The Lille Flandres and Lille interchanges (train, metro and tramway lines)

Lille Flandres interchange is composed of a railway station and an urban public transport station. The Lille Flandres Railway Station is an old construction structure station inside the city of Lille very close to the main square of Lille, and near the old part of Lille. This station opened in the $19^{\text {th }}$ century in 1848 . Its façade is the previous "Gare du Nord" from Paris that has been reconstructed in Lille in 1867. It is the second regional train traffic station in France 
after Lyon. The Lille Flandres railway station serves the regional towns with regional trains named TER (Express Regional Trains). It also links in one hour Lille to Paris with direct TGV trains.

The Lille Europe Railway station is a very modern railway station constructed to host the Northern TGV trains on the high speed railway network (see figure 1). It opened in 1994 with the opening of the Channel tunnel and the northern TGV network.

It also serves the other French region by TGV trains that go directly to the South East (Lyon, Marseille, Nice), or the East (Strasbourg). It connects the Western parts of France (Brittany to Nantes, Rennes, and South West to Bordeaux...) by means of trains that go around Paris and after westwards. All the TGVs stop at the international airport of Roissy Charles De Gaulle when going to the South.

\subsection{Spatial organisation within the interchanges}

It is essential to make interchanges attractive places to transfer in order to keeping or reaching a good level of public transport use. As travel patterns become more complex, currently many public transport users have to make transfers between different transport modes to complete their daily journeys (Di Ciommo et al. 2014). In this respect, measures oriented to improve public transport service quality are required, such as reducing the transfer inconvenience and providing a seamless travel experience. Moreover, total travel time directly influences trip choices. Good connectivity at public transport stops and stations is therefore critical to overall transportation network effectiveness (Iseki \& Taylor, 2010). Urban transport interchanges play a key role within transport network since they allow that different modes can be used in an integrated manner. However, transport stations in general must be considered multimodal facilities where travellers not only are passing through; they are also spending time in (van Hagen, 2011). For this reason, public transport users are particularly affected by the quality of the service provided.

The Lille Flandres interchange is composed of the railway, metro and tramway stations bearing the same name of "Gare Lille Flandres". Lille Flandres railway station counts 17 platforms for more than 500 trains per day and has a traffic of 20 million passengers per year (2012) and 110,000 daily users of which 70,000 take the train and 40,000 are only crossing, using services or going into its shops. Lille Flandres has a lot of connexions with the urban transport network with the Metro VAL line 1 and line 2 (located underground second level), two tramway lines towards Roubaix and Tourcoing (at intermediate level) whose stations bear the same name of Lille Flandres.

The Lille Europe railways interchange is composed of the railway station and the metro and tramway station with the same name "Gare Lille Europe". Lille Europe is the new high speed train TGV and Eurostar, Thalys and TER-GV station

It counts 4 platforms with a central 2 railway lines for passing through Eurostar trains coming from Paris and going directly to London. It connects Lille to Paris by TGV (1 hour), and to Brussels (38 minutes) and London (1 hour 20 minutes) with the Eurostar trains. Since 2014 works are undertaken on the departure concourse for the cross-Channel trains (Eurostar): they will provide new control desks, an increase of the boarding area. 
This Lille Europe station also serves regional high speed trains named TER-GV. These trains run on the high speed tracks to link the "Côte d'Opale" coastal area and the cities of Calais, Dunkirk, Boulogne sur Mer until Rang-du-Fliers at the South West of the region.

The Lille Europe railway interchange has a daily traffic of 8,500 passengers. Inside the two interchanges are present facilities such as new tickets purchase machines, new waiting lounges with special ones for the fidelity program members name "grand voyageurs", coffee shops and pubs, press kiosks, left-luggage service, toilets. Since the refurbishment of Lille Flandres railway station, other shops have opened like a sport bike-based shop.

A «mobility agency » gives information on the public transport network and sells special subscription cards (for students, scholars, etc.) at Lille Flandres underground station.

In the two stations a new color-coded information is used to display information: in blue information about railway services (platform number); in green information about the intermodal transport modes (metro, tramway, buses, taxis, self-service bikes, carsharing, ...) in yellow information about services (ticket sales counters, waiting rooms, meeting points, toilets, ...).They also offers new projects: Wi-bike (biking plugs), piano, children area in the concourse area...

Inside the interchanges information's to travellers are provided on Internet and smartphones; there is intermodal map with the location of each transport modes;

Innovations have been made for fares and ticketing information with the new "PassPass" smart card information and ticketing. On time information screenplays for train departures are located in the railway stations and in the metro Lille Flandres station; in the O'Conway pub in Lille Europe and in coffee shops. Nevertheless there is nearly no transport information in the shopping mall.

\subsection{Spatial organisation outside the interchanges}

The Lille Europe and Lille Flandres interchanges are offering numerous transport modes to access and egress the railway station. Effectively they are close to regular bus routes and one specific bus route Citadine that deserve the two railway stations and a circle route inside Lille. Two metro stations and two tramway stations serve these interchanges; outside the interchanges we can find twelve buses routes at the Lille Flandres exits and seven bus routes and long distance coaches outside the Lille Europe interchange. It also recently offers selfservice bikes in free access stations named V'Lille that are placed near the main exits and a watch out bike garage which is free for public transport passengers and train users at Lille Flandres. For these two railway stations is exist paying parking facilities.

It also counts a special "shuttle" bus to link the Lille airport and the Charleroi airport in Belgium located between the two interchanges. Car-sharing possibility is offered at Lille Flandres station (figure 3). 


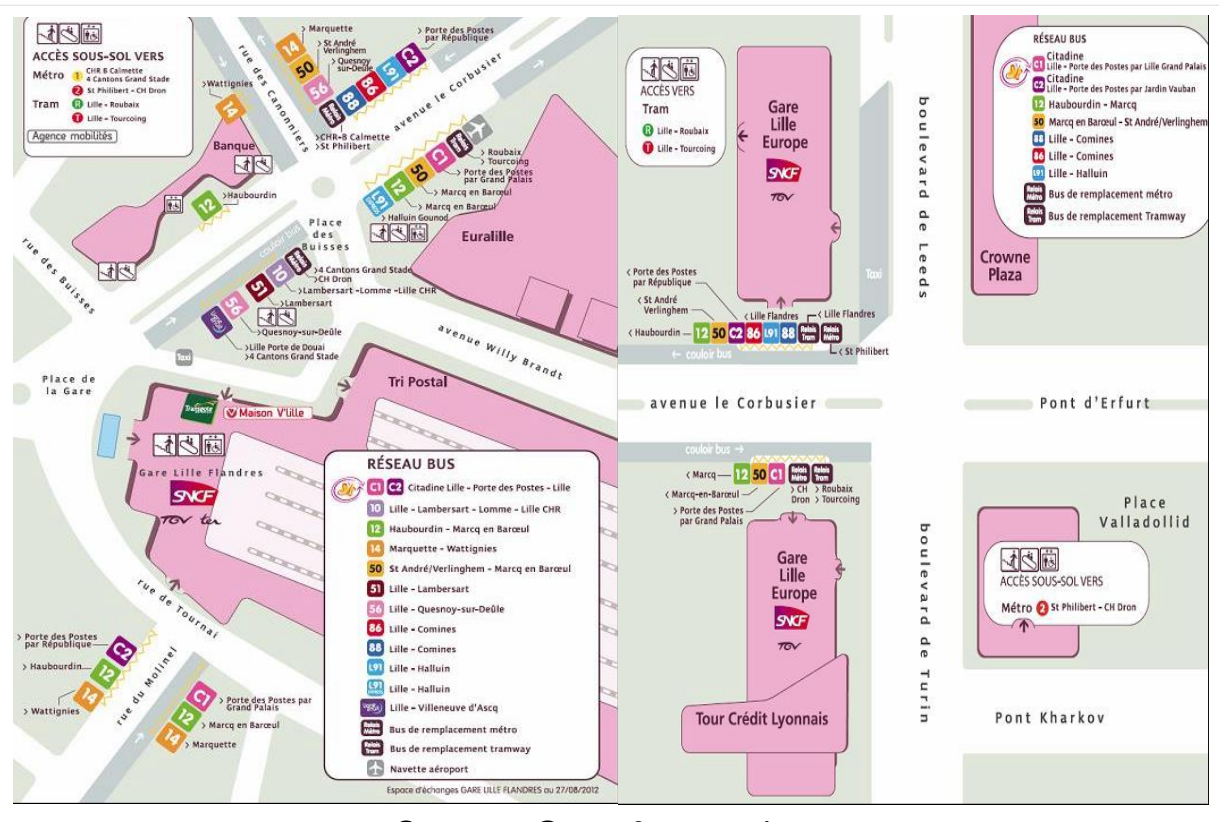

Source : Gares\&connexions

Figure 3: Access to the two Lille interchanges combination of transport modes

The Lille Flandres railway station passengers mainly come from the metro (44\%) or tramway (4\%) and flows are mainly coming from the underground access; or are walking or cycling $(35 \%)$ the fact that there is a watch out free garage for private bikes ease the use of that nonmotorised mode. The Lille Europe passengers mainly come by car and taxis (42\%) or metro and tramway (31\%). There is a big issue for making possible the modal shift to public transport modes.

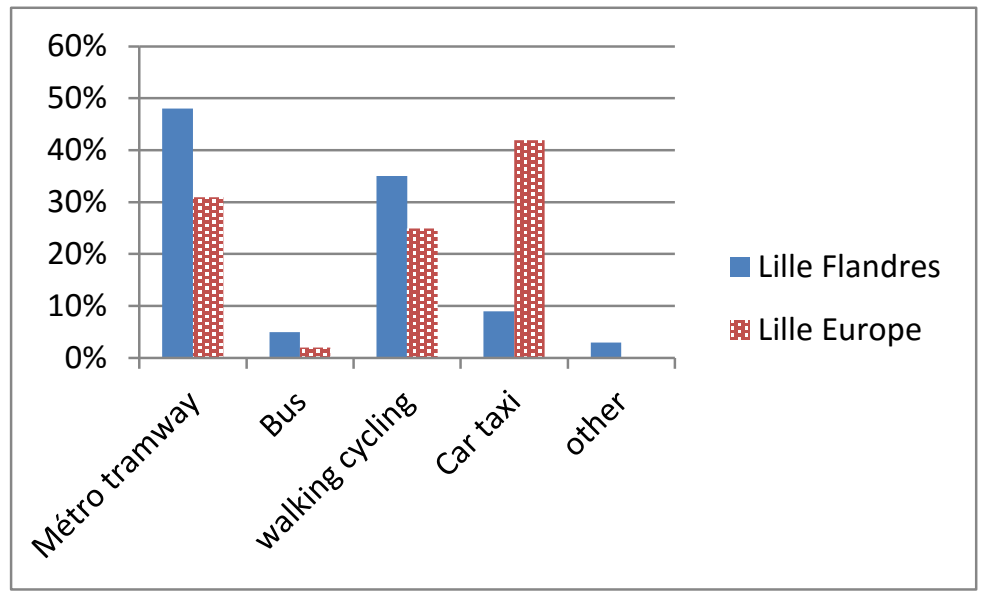

Source: Gares \& Connexions, 2014

Figure 4: Modal share of access to Lille Flandres and Lille Europe railway stations.

The differences noted in access modes for the two interchanges could be explained by the motives of travels. Effectively in Lille Flandres, there are more travels for work or study motives and in Lille Europe there are more travels for leisure of business motives explaining the importance of access by cars or taxis.

\subsection{The stakeholders' involvement}

The regional trains supply (timetables, frequency...) is ordered and financed by the Regional 
council for TER trains in Lille Flandres and TER-GV (High speed TER) in Lille Europe. The urban public transport modes are operated by Transpole (Keolis) and the urban transport authority is the Lille European Metropolis (MEL).

The railway stations are run by Gares \& Connexion and "SNCF-mobilités" is the operator. The tracks are under the property of previously RFF (Réseau Ferré de France) that became the $1^{\text {st }}$ July 2015 "SNCF Réseau". In Lille Europe, national trains are scheduled and operated by "SNCF-mobilités" and international trains belong to the Railteam network (SNCF, Eurostar, Thalys...).

In 2008 a first refurbishment was made for the Lille Flandres metro and tram stations. The Lille Flandres railway station is under refurbishment since 2013 with works on the tracks for a better train supply and from 2014 until 2015 to provide new concourse, new joint Public Transport and rail ticket office (purchase of rail or PT tickets, joint information, network maps, etc.). These works will also provide a wider access to public transports linking the ground floor level to underground levels. The two first floors of the station will be converted into a new $1,300 \mathrm{~m}^{2}$ business centre with commercial and offices spaces. The refurbishment budget is $€ 18$ million. It is shared between SNCF Gares \& Connexions ( $€ 14,019,862)$, Nord Pas-de-Calais Region $(€ 2,000,000)$, European Union $(€ 1,320,138)$, the State $(€ 660,000)$ and the City of Lille $(€ 115,500)$.

According to the interviews, the Lille interchange has identified the needs of the operators and clients before refurbishment of the interchanges. They also consulted the reduced mobility persons association and the Lille Flandres has discussion groups for the operation of the 13 regional TER routes.

\subsection{Socio economic impact of the interchange}

As highlighted by Banister and Berechman (2001) three conditions must be present in order to induce economic development. The transport investment such as a new interchange must be of significant size in order to provide new accessibility and new connections between transport modes. The economic context must reach high quality of labour forces and present underlying dynamics economic externalities at the local, regional or national level. The third condition is the existence of political willingness to implement complementary policies in order to provide a better environment and to boost the transport investment and obtain economic development. These complementary policies can be to implement a transport hub as the part of an overall larger integrated policy and/or plan aiming at (re)developing linked economic activities and urban function (re)development. Moreover they conclude that "policy design also has a crucial role in influencing and strengthening the potential impact of transport infrastructure investment on local economic development (Banister and Berechman, 2001)."

For the Lille Flandres and Lille Europe interchanges, an important urban development project Euralille was created. In the meantime the international railway station of Lille Europe was planned to host the Eurostar trains from London to Brussels and the French TGV, High Speed Trains, linking the main French towns, a political decision was taken to create a completely new neighbourhood named "Euralille" seen as an important factor of the 
new social and economic policy for the Lille Metropolis. This new neighbourhood was firstly developed as a "complex of economic functions rather than a neighbourhood" (Moulaert and al., 2001). But different development phases have been realised providing this new neighbourhood with housing for local population, local culture, conviviality, etc. A shopping mall named Euralille was created between the two intermodal railway stations (figure 2). It is $67,000 \mathrm{~m}^{2}$ and includes 164 shops and services of which one is a hypermarket. New office buildings and new housing have been constructed in the vicinity of these interchanges New coordinated planned actions are undertaken to make this development within the further development of Euralille. Three development areas are still under construction with the Euralille 1 or the CIAG (Centre International d'Affaires des Gares) international centre for businesses near the railway stations and two other developments zones a little further but linked to the two railway stations by the VAL metro line 2 .

To link transport and land-use planning, all of the planning stakeholders are involved in a Metropolitan development view (the regional council in charge of the regional planning and regional express trains development, the city of Lille, the Département, the LMCU (Lille Métropole Urban Community) that is the urban transport authority, the SNCF and Transpole the transport operators and Euralille SPL in charge of developing this area (Heddebaut, Palmer, 2014).

Two other development projects are under construction (Estienne and Escudie, 2008). The first one of 22 hectares constructed on the wastelands of the former Lille International Fair is called "Euralille 2" close to Euralille and will create a neighbourhood called "inhabited wood" with 600 housing program; offices and activities; the extensions of Lille Grand Palais the international congress centre and the headquarters of the Region and the implementation of $13,000 \mathrm{~m}^{2}$ of public facilities (schools, nurseries, kindergartens, sports equipment). The second one called "Porte de Valenciennes" is a 18 hectares program creating 1000 housing units including 360 social housing (120 social rental and 240 free rental and accessions) carried by $\mathrm{CMH}$ and $\mathrm{LMH}$ that are companies for social housing development in the Lille metropolis. $30,000 \mathrm{~m}^{2}$ of offices and $6,600 \mathrm{~m}^{2}$ of businesses and shops are being constructed and a part of this land will be converted into public spaces and squares.

\section{CONCLUSION}

We have seen that it exists an opportunity to join together the two Lille railway stations and urban Public Transport interchanges in order to combine a great urban interchange. It will procure advantages for increasing the accessibility for all destinations at urban Lille metropolis and regional level, but also at national and international level by the possibility offered by the French TGVs running on national network and the Railteam high speed trains such as Eurostar and Thalys. Despite existing barriers (complex governance framework, physical barriers, functions and logistics to revise, local constraints), all the stakeholders are willing to improve the visibility of these interchanges.

The extension of the Euralille neighbourhood is part of the Lille urban regeneration and still under construction. It will provide new housing and also social housing for low income people and new city amenities transforming it in a new place to live transforming the current 
two separated interchange towards the future one landmark interchanges with an higher share of sustainable transport modes share.

\section{REFERENCES}

Banister, D. and Berechman, Y. (2001). Transport investment and the promotion of economic growth. Journal of Transport Geography, 9(2001) 209-218.

CRTM, (2010). Plan de Intercambiadores Madrid. Consorcio Regional de Transportes de Madrid.

Di Ciommo, F. , Monzón, A., Hernandez, S., Palmer, D., Harmer, C., Millard, K., Andersen, J., Christiansen, P., Nathanail, E., Adamos, G., Tsumi, M., Poppeliers, R., Heddebaut, O., Jarvi, T., Nokkala, M., Kostiainen, J., Gabor, A., Pusztai, A., Viràg, A., Spousta, J., (2015). Deliverable 5.2, "City-HUB Handbook", City-HUB project, 16 March 2015, 125 p.

Di Ciommo, F., (2002). 'L'accessibilité: l'enjeu prioritaire de la nouvelle politique des transports publics à Naples", in Bernard Jouve, Les politiques de déplacements urbains en Europe, L'Harmattan, pp. 135-159.

Di Ciommo, F., Monzón de Cáceres, A., De Oña, R., De Oña López, J., \& Hernández del Olmo, S. (2014). Using hybrid latent class model for city-HUBs'users behaviour analysis, CIT, Santander.

Estienne, I., Escudie, E., (2008). Euralille, fiche projet, extrait du tome 3, POPSU, Plateforme d'observation des projets et stratégies urbaines, $21 \mathrm{p}$.

Heddebaut, O., Palmer, D. (2014). Multimodal city-hubs and their impact on economic and land use planning. TRA2014 Transport Research Arena 2014. Transport Solutions: from Research to Deployment - Innovate Mobility, Mobilise Innovation, Paris, France, 14-17 Apr 2014.

Hernandez, S., Monzon, A. \& De Oña, R. (2014). Urban transport interchanges: ImportancePerformance analysis for evaluating perceived quality. Submitted for publication in Transportation Research Part A.

Iseki, H., \& Taylor, B. D. (2010). Style versus Service? An Analysis of User Perceptions of Transit Stops and Stations. Journal of Public Transportation, 13(3), 23-48.

LMCU (2010). Plan de déplacements urbains de la communauté urbaine de Lille.

Moulaert, F., Salin, E., Werquin, T., (2001). Euralille: Large-Scale Urban Development and Social Polarization, European Urban and Regional Studies, $20028: 145$

Poppeliers, R., Di Ciommo, F., Heddebaut, O., Nokkala, M., Jarvi, T., (2016). Insights: Interchange management and governance in Monzón, A., Di Ciommo, F., (Ed) "CityHUBs : Sustainable and efficient urban transport interchanges”, CRC press, Taylor \& Francis, (to be published 2016)

Van Hagen, M. (2011), Waiting experience at train stations (Ph.D. Thesis). Twenty University, The Netherlands. 